\title{
Primer Note: Development of Highly Polymorphic Nuclear Microsatellite Markers for Hinoki (Chamaecyparis obtusa)
}

\author{
By M. G. IwaIZUmi ${ }^{1), *)}$, A. WATANABE ${ }^{1)}$ and K. IsodA ${ }^{2)}$
}

(Received $4^{\text {th }}$ November 2009)

\begin{abstract}
We developed 32 microsatellite markers from an enriched genomic DNA library of hinoki (Chamaecyparis obtusa), one of the most important Japanese forestry conifer species. From a total of 1,056 cloned plasmids, 96 sequence-specific primer pairs were designed from 110 candidate clones. We selected 32 primers that showed successful amplification and marked polymorphism and evaluated their characteristics using DNA from 38 C. obtusa elite trees planted in the Forest Tree Breeding Center. The markers were highly polymorphic, with the number of alleles ranging from 8 to 32 (mean: 20.09), and expected heterozygosity ranging from 0.811 to 0.958 (mean: 0.901). Progress in breeding projects and studies of the ecological genetics of this species can be expected through the use of this enlarged marker pool.
\end{abstract}

Key words: Chamaecyparis obtusa, microsatellites, forest tree breeding, genetic resources, ecological genetics.

\section{Introduction}

Together with the increase in timber production with high-quality wood, clone-by-clone management of elite trees and investigation of the mating patterns and pollen flow in seed orchards have become increasingly important in systemized forest tree breeding in Japan. It has also been important to conserve the natural genetic resources and the within-population genetic diversity against potential depletion or contamination through overcutting or plantation practices. Highly polymorphic microsatellite (simple sequence repeat; SSR) markers have enhanced molecular studies of Japanese conifer species, in particular, genotypic discrimination of clones (e.g., HIRAO et al., 2006), gene flow in seed orchards and natural populations (e.g., Moriguchi et al., 2005; Goto et al., 2005; IwAIZUMi et al., 2007; LIAN et al., 2008), and inter-population genetic structure (e.g., TAKAHASHI et al., 2005).

Hinoki (Chamaecyparis obtusa (Sieb et. Zucc.) Endl.; $2 n=22$ ) belongs to the Cupressaceae family and is one of the most important Japanese forestry conifer species. Inter-population genetic differentiation patterns in C. obtusa have been evaluated using allozymes (SHIRAISHI et al., 1987; UCHIDA et al., 1997) and cleaved amplified polymorphic sequence markers (TSUMARA et

\footnotetext{
1) Forest Tree Breeding Center, Forestry and Forest Products Research Institute, 3809-1 Ishi, Juo, Hitachi, Ibaraki 319-1301, Japan.

$\left.{ }^{2}\right)$ Kansai Regional Breeding Office, Forest Tree Breeding Center, Forestry and Forest Products Research Institute, 1043 Uetsukinaka, Shoo, Katsuta, Okayama 709-4335, Japan.

*) Corresponding author: M. G. IwAIzUMI. Tel: +81-294-39-7012; Fax: +81-294-39-7352. E-mail: ganchan@affrc.go.jp
}

al., 2007). Nuclear SSR markers have been developed in this species (NAKAO et al., 2001; MATSUMOTO et al., 2006); however, some of these markers possess insufficient polymorphisms for discrimination of individuals, or significantly positive expected null allele frequencies (MiURA et al., 2006; Miura and Watanabe, 2007). Additional SSR markers are needed for breeding projects and studies of ecological genetics. In this study, we developed 32 new SSR markers in C. obtusa, and evaluated their characteristics.

\section{Materials and Methods}

A SSR library was developed using the procedure of FUKATSU et al. (2005) using DNA fragments of a C. obtusa clone, extracted using a modified cetyl trimethylammonium bromide (CTAB) method (SHIRAISHI and WATANABE 1995) and enriched by selective hybridization with $(\mathrm{AG})_{n}$ insert repeats. The DNA fragments were amplified by polymerase chain reaction (PCR) and the products were cloned using a TOPO TA Cloning kit (Invitrogen Inc.) following the manufacturer's instructions. Recombinant clones were then sequenced using an ABI PRISM 3100 genetic analyzer with a BigDye terminator sequencing kit (Applied Biosystems Inc.). Of a total of 1,056 cloned plasmids, 345 contained SSR regions. The 110 suitable SSR regions, out of which clear sequences containing perfect and non-compounded SSR repeats could be read, were selected, 96 of which were not redundant. Primers were designed for these 96 sequences using the free software Primer 3 available on the WWW (http://frodo.wi.mit. edu/primer3/; ROZEN and SKALETSKY, 2000). We applied the M13 (-21)-tailed primer method (SCHUELKE, 2000; BOUTIN-GANACHE et al., 2001), adding the sequence (5'-TGTAAAACGACGGCCAGT-3') to the 5' end of each forward primer.

We tested the amplification and level of polymorphism in these 96 primers using DNA samples from four C. obtusa elite trees planted in the Forest Tree Breeding Center, Japan. DNA extractions of these samples were performed with procedures similar to those used for the development of the microsatellite library. PCR amplification was conducted in a total volume of $10 \mu \mathrm{L}$ containing $20 \mathrm{mM}$ Tris-HCl (pH 8.4), $0.2 \mathrm{mM}$ dNTP mix, $2 \mathrm{mM}$ $\mathrm{MgCl}_{2}, \quad 0.15 \mu \mathrm{M}$ fluorescently labeled M13 forward primer, 0.25 units Taq DNA polymerase (Invitrogen), $0.01 \mu \mathrm{M}$ M13 (-21)-tailed forward primer, $0.15 \mu \mathrm{M}$ reverse primer, and c. $10 \mathrm{ng}$ of template genomic DNA. The PCR was conducted on a GeneAmp ${ }^{\circledR}$ PCR System 9700 version 3.05 (Applied Biosystems Inc.) with touchdown PCR as follows: an initial denaturation at $94^{\circ} \mathrm{C}$ for $1 \mathrm{~min}$, then 10 cycles of $94^{\circ} \mathrm{C}$ for $30 \mathrm{sec}$, varying the 
Table 1. - Characteristics of 32 microsatellite markers evaluated using 38 Chamaecyparis obtusa elite trees, and the segregation ratios of alleles for 16 offspring derived from seeds produced by an open-pollinated mother clone.

\begin{tabular}{|c|c|c|c|c|c|c|c|c|}
\hline $\begin{array}{c}\text { Locus } \\
\text { (Accession No.) }\end{array}$ & $\begin{array}{l}\text { PCR primer sequence } \\
\qquad\left(5^{\prime}-3^{\prime}\right)\end{array}$ & $\begin{array}{l}\text { Size range } \\
\quad(b p)\end{array}$ & $n_{\mathrm{a}}$ & $n_{\mathrm{e}}$ & $H_{\mathrm{O}}$ & $H_{\mathrm{E}}$ & & $\begin{array}{l}\text { Segregation ratio } \\
\text { (not identified) }^{\dagger}\end{array}$ \\
\hline $\begin{array}{l}\text { bcco0002 } \\
(\mathrm{AB} 535492)\end{array}$ & $\begin{array}{l}\text { F: ATGGACAAGAGTCTCCACCTG } \\
\text { R: TGCCCTCATCCTTCTATTAAGC }\end{array}$ & $132-180$ & 21 & 12,28 & 0,892 & 0,919 & & $5: 4(7)$ \\
\hline $\begin{array}{l}\text { bcco0032 } \\
(\mathrm{AB} 535493)\end{array}$ & $\begin{array}{l}\text { F: CTCCTTAAGACCACTTAGGACACC } \\
\text { R: GAAGCATTGGCAAGATATCATAGA }\end{array}$ & $154-231$ & 22 & 16,40 & 0,324 & 0,939 & $* * *$ & $9: 6(1)$ \\
\hline $\begin{array}{l}\text { bcco0037 } \\
\text { (AB535494) }\end{array}$ & $\begin{array}{l}\text { F: ATTGTGGGAGGATGTTGTTAGATT } \\
\text { R: СCCTCTCTTCCCTCCTATTATGTT }\end{array}$ & $168-235$ & 23 & 12,78 & 0,868 & 0,922 & & $5: 5(6)$ \\
\hline $\begin{array}{l}\text { bcco0048 } \\
(\mathrm{AB} 535495)\end{array}$ & $\begin{array}{l}\text { F: ATCACAAGGAACCAACAACTGTC } \\
\text { R: AGATTTGAACATGTGACCTACACG }\end{array}$ & $169-221$ & 25 & 15,96 & 0,868 & 0,937 & & $3: 5(8)$ \\
\hline $\begin{array}{l}\text { bcco0057 } \\
\text { (AB535496) }\end{array}$ & $\begin{array}{l}\text { F: TTGTCAGTCATGTTGCCAAAG } \\
\text { R: TCCATCCAAGGTGTCCTAGTG }\end{array}$ & $87-115$ & 11 & 8,73 & 0,895 & 0,885 & & $3: 8(4)$ \\
\hline $\begin{array}{l}\text { bcco0060 } \\
(\text { AB535497) }\end{array}$ & $\begin{array}{l}\text { F: CAATGATTAGATCCGTTCACGA } \\
\text { R: GCGAGACATCTAGAAATAAAAGAGG }\end{array}$ & $219-271$ & 16 & 7,89 & 0,842 & 0,873 & & $9: 3(4)$ \\
\hline $\begin{array}{l}\text { bcco0086 } \\
\text { (AB535498) }\end{array}$ & $\begin{array}{l}\text { F: ATCCATCCCAAGATCAAGAATG } \\
\text { R: ATGCAAGTTTCTCTCCCATGAT }\end{array}$ & $153-200$ & 22 & 14,56 & 0,946 & 0,931 & & $5: 4(6)$ \\
\hline $\begin{array}{l}\text { bcco0112 } \\
\text { (AB535499) }\end{array}$ & $\begin{array}{l}\text { F: ACGCCTTTTGTCTTCATTGG } \\
\text { R: GTGGGGCCAACACATTAAAC }\end{array}$ & $88-130$ & 15 & 7,27 & 0,868 & 0,863 & & $4: 5(7)$ \\
\hline $\begin{array}{l}\text { bcco0404 } \\
(\mathrm{AB} 535500)\end{array}$ & $\begin{array}{l}\text { F: GGGAAGGTTCATCTAATGCTCA } \\
\text { R: ATCTTGAACTTGGGCTGAAAAA }\end{array}$ & $172-241$ & 21 & 9,50 & 0,895 & 0,895 & & $7: 5(4)$ \\
\hline $\begin{array}{l}\text { bcco0406 } \\
\text { (AB535501) }\end{array}$ & $\begin{array}{l}\text { F: AATCAATGAGGTCACCATCCAC } \\
\text { R: ATCATCCTGATGAGGCCTTG }\end{array}$ & $154-232$ & 32 & 24,07 & 0,868 & 0,958 & & $3: 6(7)$ \\
\hline $\begin{array}{l}\text { bcco0455 } \\
(\mathrm{AB} 535502)\end{array}$ & $\begin{array}{l}\text { F: TGGTCCAACTAACTAGCCATGT } \\
\text { R: CCAATGGAATCTATGCTCTTTCA }\end{array}$ & $154-219$ & 22 & 16,22 & 0,842 & 0,938 & $* * *$ & $6: 6(4)$ \\
\hline $\begin{array}{l}\text { bcco0508 } \\
\text { (AB535503) }\end{array}$ & $\begin{array}{l}\text { F: TTGGAATGGACAATATCGCTAC } \\
\text { R: ATCTCCTTGGAAATTCATCCAC }\end{array}$ & $152-174$ & 8 & 5,30 & 0,861 & 0,811 & & $8: 6(2)$ \\
\hline $\begin{array}{l}\text { bcco0556 } \\
\text { (AB535504) }\end{array}$ & $\begin{array}{l}\text { F: CTTGAGAAATCTCCGGTCTTGT } \\
\text { R: AAAAATGGGTATAGGCAATCATGT }\end{array}$ & $116-169$ & 16 & 6,86 & 0,556 & 0,854 & $* * *$ & $4: 6(5)$ \\
\hline $\begin{array}{l}\text { bcco0756 } \\
\text { (AB535505) }\end{array}$ & $\begin{array}{l}\text { F: GCTGACATGTTTAGGAGGCAAT } \\
\text { R: CCATGGCTAAATATTCCCAGA }\end{array}$ & $135-148$ & 9 & 3,61 & 0,605 & 0,723 & & $5: 3(8)$ \\
\hline $\begin{array}{l}\text { bcco0763 } \\
\text { (AB535506) }\end{array}$ & $\begin{array}{l}\text { F: TGTATTGTTTGGGTGAGTGGAC } \\
\text { R: AACGCATTATAACATGCTCGTG }\end{array}$ & $128-175$ & 19 & 13,03 & 0,917 & 0,923 & & $2: 10(3)^{*}$ \\
\hline $\begin{array}{l}\text { bcco0835 } \\
\text { (AB535507) }\end{array}$ & $\begin{array}{l}\text { F: AGATTTTAGATGGGAATCCATTG } \\
\text { R: ATACTTTACTGGGCTGGTGGTC }\end{array}$ & $134-181$ & 17 & 11,19 & 0,868 & 0,911 & & $3: 8(5)$ \\
\hline $\begin{array}{l}\text { bcco0852 } \\
\text { (AB535508) }\end{array}$ & $\begin{array}{l}\text { F: GGTGATCATCAATCACTATCTTTG } \\
\text { R: TGAACAAGGATGAAGGAAACAA }\end{array}$ & $133-212$ & 28 & 19,01 & 0,946 & 0,947 & & $10: 4$ (2) \\
\hline $\begin{array}{l}\text { bcco0883 } \\
(\mathrm{AB} 535509)\end{array}$ & $\begin{array}{l}\text { F: AAAAGGTGACATGTGATTGTGC } \\
\text { R: CCATTAAAAAGTGGAGGTGAGG }\end{array}$ & $92-134$ & 18 & 11,84 & 0,895 & 0,916 & & $8: 2(6)$ \\
\hline $\begin{array}{l}\text { bcco0919 } \\
(\mathrm{AB} 535510)\end{array}$ & $\begin{array}{l}\text { F: CCGAGGCACATGTTTACTAGGT } \\
\text { R: AAGCCACTCCAAAAGTCAAAAA }\end{array}$ & $101-153$ & 19 & 13,50 & 0,921 & 0,926 & & $2: 6(8)$ \\
\hline $\begin{array}{l}\text { bcco0934 } \\
(\mathrm{AB} 535511)\end{array}$ & $\begin{array}{l}\text { F: ATCACCAACGATGATACCCACT } \\
\text { R: CATACAATCTTACTAGGCAAGGTG }\end{array}$ & $121-167$ & 20 & 10,13 & 0,833 & 0,901 & & $5: 8(3)$ \\
\hline $\begin{array}{l}\text { bcco1012 } \\
\text { (AB535512) }\end{array}$ & $\begin{array}{l}\text { F: AAGGGGAAGACCCAAAATACAT } \\
\text { R: ACTGATTCACACCCCTCTCTGT }\end{array}$ & $120-191$ & 22 & 9,74 & 0,889 & 0,897 & & $5: 3(8)$ \\
\hline $\begin{array}{l}\text { bccol016 } \\
\text { (AB535513) }\end{array}$ & $\begin{array}{l}\text { F: TGTGGAACAAGGATTATGATGG } \\
\text { R: CCCACCATCTCATAAGGTTCTC }\end{array}$ & $216-276$ & 21 & 12,39 & 0,711 & 0,919 & $*$ & $4: 5(7)$ \\
\hline $\begin{array}{l}\text { bccol038 } \\
\text { (AB535514) }\end{array}$ & $\begin{array}{l}\text { F: TGCAATGCATATCTTCTCCAAG } \\
\text { R: TCCATTTTGGGCTATCTCTCTC }\end{array}$ & $166-234$ & 24 & 14,26 & 0,595 & 0,930 & $* * *$ & $5: 8(3)$ \\
\hline $\begin{array}{l}\text { bccol074 } \\
\text { (AB535515) }\end{array}$ & $\begin{array}{l}\text { F: AGTGTTTTGAAAGCCTGAAGGA } \\
\text { R: AAATTCTTGGTGGTAGGATGGA }\end{array}$ & $192-254$ & 20 & 10,82 & 0,711 & 0,908 & $* *$ & $4: 7(5)$ \\
\hline $\begin{array}{l}\text { bcco1083 } \\
\text { (AB535516) }\end{array}$ & $\begin{array}{l}\text { F: CACAACAATCAGTCAGTGACCA } \\
\text { R: AAAAGGGGAGATGAGATGTGTG }\end{array}$ & $115-165$ & 19 & 11,34 & 0,657 & 0,912 & $* *$ & $9: 3(4)$ \\
\hline $\begin{array}{l}\text { bccol121 } \\
\text { (AB535517) }\end{array}$ & $\begin{array}{l}\text { F: CCTGAAAGGGAACAAAGATGTC } \\
\text { R: CCAACAAAACACAACAGGAAAA }\end{array}$ & $166-225$ & 19 & 6,67 & 0,816 & 0,850 & & $5: 7(4)$ \\
\hline $\begin{array}{l}\text { bccol150 } \\
\text { (AB535518) }\end{array}$ & $\begin{array}{l}\text { F: GTGACACTTGGCACACACCTAT } \\
\text { R: AAGGAAGGAAGGAAGGAAGAAG }\end{array}$ & $197-237$ & 20 & 13,19 & 0,868 & 0,924 & & $8: 5(3)$ \\
\hline $\begin{array}{l}\text { bccol261 } \\
\text { (AB535519) }\end{array}$ & $\begin{array}{l}\text { F: TGATTGTAACCCTAAGCCCTTT } \\
\text { R: CCCCTCTTTTTACATCTTACGG }\end{array}$ & $167-262$ & 32 & 22,89 & 0,941 & 0,956 & & $9: 2(4) *$ \\
\hline $\begin{array}{l}\text { bccol264 } \\
(\mathrm{AB} 535520)\end{array}$ & $\begin{array}{l}\text { F: CGGTTCACAAAAAGACAACATC } \\
\text { R: CACTCCATGCAATTTACTGAGG }\end{array}$ & $140-196$ & 17 & 9,26 & 0,583 & 0,892 & * & $9: 6(0)$ \\
\hline $\begin{array}{l}\text { bcco1309 } \\
(\mathrm{AB} 535521)\end{array}$ & $\begin{array}{l}\text { F: AAAGGATTAAATCTAAGGGGATGG } \\
\text { R: GGAGGGATGGATAGATTTTGGT }\end{array}$ & $144-224$ & 20 & 12,39 & 0,842 & 0,919 & & $6: 3(7)$ \\
\hline $\begin{array}{l}\text { bccol318 } \\
\text { (AB535522) }\end{array}$ & $\begin{array}{l}\text { F: CCTTGCTCAAAGAAGCAACTCT } \\
\text { R: GCACGTGCACCCTATTTAAGTC }\end{array}$ & $129-206$ & 24 & 17,72 & 0,921 & 0,944 & & $3: 9(4)$ \\
\hline $\begin{array}{l}\text { bccol360 } \\
\text { (AB535523) }\end{array}$ & $\begin{array}{l}\text { F: GCTAAGAAGTGTGTGGGGGTAG } \\
\text { R: CATCAACAACAAACCATCCATC }\end{array}$ & $169-244$ & 21 & 5,22 & 0,842 & 0,809 & & $6: 4(6)$ \\
\hline Mean & & - & 20,09 & 12,06 & 0,809 & 0,901 & & - \\
\hline
\end{tabular}

$n_{\mathrm{a}}$ : number of alleles; $n_{\mathrm{e}}$ : effective number of alleles; $H_{\mathrm{O}}$ and $H_{\mathrm{E}}$ : observed and expected heterozygosities. *, **, ***: Significant deviation from Hardy-Weinberg equilibrium or from the expected segregation ratio $(P<0.05$, $P<0.01, P<0.001$, respectively). $\uparrow$ : Number of offspring samples whose maternal allele was not identified because they had identical genotypes to the mother clone. 
annealing temperature from $62^{\circ} \mathrm{C}$ to $57^{\circ} \mathrm{C}$ by decreasing by $0.5^{\circ} \mathrm{C}$ per cycle for $30 \mathrm{sec}$, then $72^{\circ} \mathrm{C}$ for $90 \mathrm{sec}$, then 20 additional cycles of $94^{\circ} \mathrm{C}$ for $30 \mathrm{sec}, 57^{\circ} \mathrm{C}$ for $30 \mathrm{sec}$, and $72^{\circ} \mathrm{C}$ for $90 \mathrm{sec}$, and a final extension at $72^{\circ} \mathrm{C}$ for $10 \mathrm{~min}$. To determine the amplified fragment lengths, amplified PCR products of 96 loci were analyzed separately (not multiplexed) with an ABI PRISM 3100 genetic analyzer. The size of amplified fragments was standardized with a GENESCAN 500-Liz Size Standard (Applied Biosystems Inc.), and genotyped with a Genotyper $^{\circledR} 3.7$ (Applied Biosystems Inc.). The 32 primers that showed successful amplifications and marked polymorphism were selected as the developed markers.

These 32 markers were further tested using DNA samples from 34 C. obtusa elite trees planted in the Forest Tree Breeding Center, thereby evaluating their characteristics for a total of 38 individuals. These archived clones were selected from provenances located throughout southeastern Honshu, Japan, from Haramachi, Fukushima Prefecture $\left(37^{\circ} 39^{\prime} \mathrm{N}, 140^{\circ} 54^{\prime} \mathrm{E}\right)$ to Shinshiro, Aichi Prefecture $\left(35^{\circ} 06^{\prime} \mathrm{N}, 1^{\circ} 7^{\circ} 29^{\prime} \mathrm{E}\right)$. The number of alleles $\left(n_{\mathrm{a}}\right)$, the effective number of alleles $\left(n_{\mathrm{e}}\right)$, the observed and expected heterozygosity $\left(H_{\mathrm{O}}\right.$ and $H_{\mathrm{E}}$, respectively), and the deviation from Hardy-Weinberg Equilibrium (HWE) were calculated for the 32 loci using GenAlEx 6.2 (SMOUSE et al., 2008).

\section{Results and Discussion}

Characteristics of 32 microsatellite markers developed are shown in Table 1. No individuals had more than two alleles per locus at any of the 32 loci. Most of the markers were highly polymorphic and the mean number of alleles of the 32 loci was more than 20 . The mean $n_{\mathrm{e}}$ values were also high relative to the mean $n_{\mathrm{a}}$, although with large variations among loci (3.61 (bcco0756) to 24.07 (bcco0406)). The markers were highly heterozygous and the mean $H_{\mathrm{E}}$ of the 32 loci was greater than 0.9. Eight loci deviated significantly from $\mathrm{HWE}$ $(P<0.05)$ and the lower $H_{\mathrm{O}}$ values compared with each of their $H_{\mathrm{E}}$ values. This is probably a result of regional genetic sub-structuring of the sample origins or the presence of null alleles. When the deviation from linkage disequilibrium was examined using GENEPOP on the Web (http://genepop.curtin.edu.au/; RAYMOND and Rousset, 1995), 10 locus pairs (bcco0032/bcco0112, bcco0037/bcco1150, bcco0060/bcco1083, bcco0112/bcco0835, bcco0112/bcco1083, bcco0112/bcco1121, bcco0556/bcco1360, bcco0756/bcco1012, bcco1083/bcco1121 and bcco1121/bcco1318) showed significant deviations from random association $(P<0.05)$. Mendelian inheritance of the 32 markers was confirmed using 16 offspring derived from seeds produced by an open-pollinated mother clone in which the genotypes for each locus are heterozygous (Table 1). Based on the chi-square tests for independence $\left(\chi^{2}\right)$, the segregation ratios of only two markers (bcco0763 and bcco1261) out of the 32 deviated significantly from the expected ratio $(1: 1 ; P<0.05)$.

In this study, we developed additional microsatellite markers for $C$. obtusa that have various characteristics suitable for clone-by-clone management, gene flow, and evaluation of inter-population genetic structure. The choice of suitable markers or marker combinations may differ according to project or research objectives, although lower null allele frequency would commonly be an important option. For example, in the field of forest tree breeding, uncomplicated allele peaks for easier genotyping would be preferred in order to genotype and then manage an enormous number of archived clones and their saplings; for gene flow studies involving parentage analysis, in contrast, higher polymorphisms or heterozygosities might be regarded as more important. Markers with little deviation from the expected segregation ratio under Mendelian inheritance would be reliable to examine inter-population genetic structure by analyzing at neutral loci. Progress can be expected in breeding projects and studies of the ecological genetics of C. obtusa through the use of this enlarged marker pool.

\section{Acknowledgement}

We thank M. TAKAHASHI, N. MiYAmoto, M. MiURA and the other members of the Forest Tree Breeding Center for their ongoing advice and encouragement during this study; M. KURITA and T. HIRAO for helpful guidance with the cloning and sequencing analysis technique; and A. Matsumoto and two anonymous reviewers for valuable comments on the manuscript. We express our special thanks to K. Kato, T. KaminAGA, and M. SHIBATA for their assistance in the laboratory.

\section{References}

Boutin-Ganache, I., M. Raposo, M. Raymond and C. F. DESCHEPPER (2001): M13-tailed primers improve the readability and usability of microsatellite analyses performed with two different allele-sizing methods. BioTechniques 31: 1-3.

Fukatsu, E., K. Isoda, T. Hirao, M. TAKahashi and A. WATANABE (2005): Development and characterization of simple sequence repeat DNA markers for Zelkova serrata. Mol Ecol Notes 5: 378-380.

Goto, S., A. Watanabe, F. Miyahara and Y. Mori (2005): Reproductive success of pollen derived from selected and non-selected sources and its impact on the performance of crops in a nematode-resistant Japanese black pine seed orchard. Silvae Genetica 54: 69-76.

Hirao, T., A. Watanabe, Y. Goto-Fukuda, T. Kondo and K. TAKATA (2006): Discrimination of Sugi (Cryptomeria japonica D. Don) Plus-tree clones using SSR marker analysis. J Jpn For Soc 88, 202-205 (in Japanese with English summary).

IWAizUmi, M. G., A. WATANABE and M. UbuKata (2007): Use of different seed tissues for separate biparentage identification of dispersed seeds in conifers: confirmations and practices for gene flow in Pinus densiflora. Can J For Res 37: 2022-2030.

Lian, C., S. Goto, T. Kubo, Y. TAKahashi, M. NaKagawa and T. Hogetsu (2008): Nuclear and chloroplast microsatellite analysis of Abies sachalinensis regeneration on fallen logs in a subboreal forest in Hokkaido, Japan. Mol Ecol 17: 2948-2962.

Matsumoto, A., N. Tani, X-G. Li, Y. Nakao, N. Tomaru and Y. TSUmuRA (2006): Development and polymorphisms of microsatellite markers for hinoki (Chamaecyparis obtusa). Mol Ecol Notes 6: 310-312. 
Miura, M., M. Kubota, S. Kurinobu and A. Watanabe (2006): Clone identification of Hinoki cypress plus-tree using SSR markers in Kanto breeding region. Kanto J For Res 57: 135-136.

MiURA, M. and A. WATANABE (2007): Clone identification of Hinoki cypress plus-tree using 7 SSR markers and detection of contaminated clones in a breeding orchard. Kanto J For Res 58: 245-246.

Moriguchi, Y., N. TANi, S. Itoo, F. Kanehira, K. TANaKA, H. Yomogida, H. TAIRA and Y. Tsumura (2005): Gene flow and mating system in five Cryptomeria japonica D. Don seed orchards as revealed by analysis of microsatellite markers. Tree Genetics and Genomes 1: 174-183.

Nakao, Y., H. Iwata, A. Matsumoto, Y. Tsumura and N. TOMARU (2001): Highly polymorphic microsatellite markers in hinoki (Chamaecyparis obtusa). Can J For Res 31: 2248-2251.

RAYMOND, M. and F. Rousset (1995): GENEPOP (version 1.2): population genetics software for exact tests and ecumenicism. J Hered 86: 248-249.

Rozen, S. and H. J. Skaletsky (2000): Primer3 on the WWW for general users and for biologist programmers, pp. 365-386. In: Bioinformatics Methods and Protocols: Methods in Molecular Biology, edited by S. KRAWETZ and S. Misener. Humana Press, Totowa/NJ.
SCHUELKe, M. (2000): An economic method for the fluorescent labeling of PCR fragments. Nature Biotechnology 18: $233-234$.

SHIRAISHI, S., H. KAMINAKA and N. OHYAMA (1987): Genetic variation and differentiation recognized at two allozyme loci in Hinoki (Chamaecyparis obtusa). J Jpn For Soc 69: 88-93 (in Japanese with English summary).

Smouse, P. E., R. Peakall and E. Gonzales (2008): A heterogeneity test for fine-scale genetic structure. Mol Ecol 17: 3389-3400.

TAKAHAShI, T., N. TANI, H. TAIRA and Y. Tsumura (2005): Microsatellite markers reveal high allelic variation in natural populations of Cryptomeria japonica near refugial areas of the last glacial period. J Plant Res 118: 83-90.

Tsumura, Y., A. Matsumoto, N. TANi, T. Ujino-Ihara, T. KADO, H. IwATA and K. UCHIDA (2007): Genetic diversity and the genetic structure of natural populations of Chamaecyparis obtusa: implications for management and conservation. Heredity 99: 161-172.

UChida, K., N. Tomaru, T. TOMarU, C. YAmamoto and K. OHBA (1997): Allozyme variation in natural populations of hinoki, Chamaecyparis obtusa and its comparison with hinoki plus-trees selected from artificial stands. Breed Sci 47: 7-14.

\title{
Short Note: Cross-Species Amplification and Characterization of Pinus Chloroplast Microsatellite Markers in Cedrus deodara Roxb.
}

\author{
By H. S. Ginwal *), P. Chauhan, S. Barthwal, A. Sharma and R. Sharma ${ }^{1)}$ \\ Division of Genetics and Tree Propagation, Forest Research Institute, \\ P.O.I.P.E Kaulagarh Road, Dehradun 248195 (Uttarakhand), India
}

(Received $18^{\text {th }}$ December 2009)

\begin{abstract}
The study reports the transferability of chloroplast microsatellite markers developed for Pinus species to Cedrus deodara. A total of 49 primer pairs (both nuclear and chloroplast) of Pinus species were tested in $C$. deodara out of which 21 chloroplast primers showed positive amplification and 20 were found polymorphic. The primers were screened on 100 adult trees of two natural populations of $C$. deodara. Using twenty cpSSR primers, a total of 64 variants were found which combined in 70 different haplotypes. The total haplotype diversity in two populations was 0.860 and 0.876 with a mean of 0.868 . These sets of markers can further be used for population genetic studies and characterization in
\end{abstract}

1) Himalayan Forest Research Institute, Panthaghati, Shimla (H.P.) India.

*) Author for correspondence: Dr. H. S. GINwAL.

E-mail: ginwalhs@icfre.org; ginwalhs@rediffmail.com
C. deodara for which no cpSSR markers have been reported till date.

Key words: Cross-amplification, cpSSRs, Cedrus deodara, microsatellite, genetic diversity.

Cedrus deodara (deodar), also known as Indian cedar is the most important among the Indian conifers. It is an important timber species of Western Himalayas at elevation ranging from $1200 \mathrm{~m}$ to $3050 \mathrm{~m}$ (TIWARI, 1994). It covers an area of about 0.2 million hectares in India mainly in the states of Jammu \& Kashmir, Himachal Pradesh and Uttarakhand. The species is in great demand for its timber and had been subjected to exploitation for centuries. Natural deodar forests are under great pressure not only due to human impact but also due to the changing weather conditions. In spite of the importance of $C$. deodara forests, limited information is available on their basic biology and genetic variability. 